\title{
Banditry in Semarang, 1950-1958
}

\author{
Joseph Army Sadhyoko, ${ }^{*}$ Agustinus Supriyono, Dhanang Respati Puguh \\ Master Program of History, Faculty of Humanities, Diponegoro University \\ *Corresponding Author: josepharmy16@gmail.com
}

\begin{abstract}
This article discusses about banditry that occurred in Semarang during the period of 1950-1958 with the problem focus on the causes of the

Received: banditry, types of banditry, and mitigation. Through the historical 12 April 2017 method, this article reconstructs those problems by using the approach of Accepted: social reality of crime concept. In result, the banditry happened in the 17 May 2017 aftermath of the independence war, occurred due to economic difficulties, the reorganization and rationalization program, and the circulation of guns that was uncontrolled.
\end{abstract}

Keywords: Semarang; Banditry; Social reality of crime.

\section{Introduction}

Nationally, banditry cases have not been widely discussed. There are only at least two cities in Indonesia during the War of Independence and Post-War Independence discussing these cases. These cities were Yogyakarta and Jakarta. As for Semarang, there was only a few people knowing how far the banditry had occurred in the city (Fauzi, 2005; Budi, 1998; Purwanto, 2005).

In general, Independence War taking place within the period 1945-1949 led to the destruction of many infrastructure facilities and bad economic conditions. Therefore, it was important for the government to carry out immediate improvements in the sector of physical and economic development. Meanwhile, in the sector of employment, both civilian and military require restructuration and rationalization (Rera) at the post-War of Independence. Rera's policy was applied by Government of the Republic of Indonesia on January 1948. Minister Mohammad Hatta, who became head of government at that time, was eager to create conditions "one soldier one commando" (Djamhari, 2012:49-50).

An excessive number of fighters and the presence of military formation outside the regular army was a concern of the central government. Therefore, their existence had to be regulated through this Rera policy. The Rera policy needed to regulate not only the fighters but also Central and local governments in order to reorganize scattered civil servants during the war. Many employees were evacuated to safe places. All of them had to be rearranged in order to fill the posts of government and the defense of the state ideally and proportionately. In addition, this policy was 
expected to save the lucrative state budget and to immediately restore the state condition that was unstable due to war (Ricklefs, 1992:355-360).

Along with the struggle for full sovereignty, the Indonesian government in practice did not follow Rera's policies consistently. Nationally, Rera was enacted on June 1950 by mobilizing some 70,000 former soldiers to be returned to society. 25,000 of them were from Java. Central government promised that the former soldiers would get jobs immediately according to their interests, particularly in agriculture and carpentry (Suara Merdeka, 5 June 1950:2).

In national scale, Rera's policy was much too late when compared to Central Java Province. Rera's policy had been enacted since April 1950 by returning the exstudent army of 2,500 people to the community. 90 percent of that amount were requested by the government to go back to school, while the rest were required to find job independently and some also personally chose to pursue military education. Meanwhile, in Semarang, the Rera's policy was enacted a month later. On May 1950 the city of Semarang received about 3,000 former student soldiers from approximately 10,000 former soldiers to be returned to Central Java Province. The municipal government even planned to accommodat former student soldiers who were graduated from junior and senior high school in a student dormitory. This dormitory was planned to be built in the area of Jalan Halmahera and Jatingaleh. For the remaining approximately 7,000 former soldiers in Central Java, the provincial government was still seeking funds to finance the training for students' skills (Suara Merdeka, 26 May 1950:4).

Rera imposed by the central and regional governments clearly had impact to the increase in the number of unemployed in Indonesia at the post-War of Independence, especially for the fighters of the War of Independence. They were the main target of the policy. As a result, there were many fighters felt anxious. Those who had struggled to sacrifice body and soul for the country during the War of Independence were not accommodated in the military units formed by the government of the Republic of Indonesia. There were some former fighters who felt that they had been left by the government. Those who had been struggling for obtaining compensation, such as obtaining decent jobs, life-long security, and of course the future of their families after the state was truly sovereign (Djamhari, 4950). Unemployed fighters and civilians were clearly the burden of the state and were forced to be mobilized immediately, through skill, transmigration, education, and exclusively for ex fighters were incorporated into the National Reserve Corps (CTN) (Poesponegoro \& Susanto, 2010:302).

The issues of injustice, dissatisfaction, and the desire of some Dutch businessmen felt fear that their assets would be taken by the republic to the emergence of various resistance against the government of the Republic of Indonesia. One of them was the Ratu Adil Armed Force (APRA) which had a major impact in the early 1950s.

The presumption of APRA sympathizers infiltration was widely known by the army in Central Java. People who knew how cruel APRA action in Bandung became 
worry that the rebellion would occur in their area, even some also suspected that APRA sympathizers began to commit criminal acts. The worried condition was seen in the surrender of Central Java Province from the military emergency government to the civil government (Suara Merdeka, 11 February 1950:4).

Overste Suprapto tried to reduce these fears and concerns by explaining that Central Java province would remain safe, although it was suspected that there were APRA sympathizers hiding in the province. The influence of widespread sympathizers according to Suprapto could be prevented by providing adequate employment, so the number of unemployed was reduced. Suprapto suspected that the unemployment during the post-War Independence would be very potential to be recruited in the new APRA movement (Suara Merdeka, 11 February 1950:4). ${ }^{1}$

The concerns arising from the community were not just about APRA. They were also suspicious on the former fighters in the War of Independence. Some cases that occurred in the War of Independence in some areas of Central Java, such as Boyolali and Surakarta, as well as Pemalang, Brebes, and Tegal showed that the fighters acted as Bandit (Ibarahim, 2004; Lucas, 1989). In addition, there were bandits exploiting the unstable regional situation during post-War of Independence.

Based on this background, this article raises the study of social history on banditry in a unique urban area and Semarang was selected as the object of the study. First, this city was selected because there were various presumptions that during the post-revolutionary era of Independence, Semarang was a center of government and it had a rapid economy, so the city was targeted by the bandits who come in line with the increasing urbanization flow. Second, Semarang is the capital of Central Java Province during post-War of Independence which had a heroic national historical narrative with the Five Days Battle. However, of the fighters who participated in the battle, there were some fighters who had no place in the military service. Therefore, they joined with the bandits. Third, in general, the city that tried to improve their life during post-war city of Independence would have difficulty in disciplining and securing city due to shortage of security personnel. Semarang experienced the condition, so that banditry was tried to be overcame effectively.

The social reality of crime growing in the city should have been able to bind city governments, law enforcers, and townspeople to jointly overcome banditry, in addition to the ability to know, understand, and cut the root of the banditry emergence that actually took place in the city of Semarang in the decade of 1950's. Semarang had heritage of military and police troops from Dutch and Japanese experiencing in the battlefield.

Based on these descriptions, the main problem discussed in this article is why there was a banditry in Semarang during psot-War of Independence, 1950-1958? Meanwhile, in order to be able to answer the main problems above, there are several questions.

${ }^{1}$ The rank of a middle officer in the army having the equal level of lieutenant colonel. 
1. What were the causes of the emergence of banditry in Semarang?

2. Who were the bandits, what kind of banditry took place in Semarang, why did they choose to act in Semarang, who were their targets, and where was the area in Semarang most often attacked by bandits?

3. What was the most effective handling and outcomes achieved by local government, law enforcers, and townspeople in order to overcome the danger caused by banditry in Semarang?

\section{Method}

The method used in this research is historical method. This method have four stages (Notosusanto, 1964:5). The first is the heuristic or process in finding and collecting sources and data relevant to the research problems. Data sources are obtained from libraries, archives, and newspaper offices (Abdullah, 2013:9). In this stage, there is also a critic to determine the source authenticity and the credibility level of the sources that being worked on. The next stage is interpretation on the data and facts obtained. In this stage, the synthesis of data and facts is performed to go to the last stage, that is historiography. This method result in systematic, scientific, and easy-tounderstand of historical writing (Kuntowijoyo, 2005:100-101).

\section{Results and Discussion}

\section{Banditry Roots}

Almost all major cities in Indonesia still had various social problems after the recognition of independence. Poverty, low levels of education, destruction of public infrastructure (office building) and economic (plantation and industrial), increasing in urbanization, and rampant unemployment (civil servants and soldiers) were burdens that had to be resolved soon (Ricklefs, 1992:355-359). Semarang became one of the big cities in Indonesia that experienced such condition. The city had to rebuild its chaotic infrastructure and bureaucracy due to war and omnipotence by the colonial authorities. Development process could not be separated from the local government policies that saw the development of the population from various aspects of life.

In addition to the issuance of weapons control and the use of military attributes, the problem of urbanization during post-War of Independence became problematic for the government of Semarang. On August 1950, Demak had experienced severe drought due to a long dry season. The wells and rivers were dry, so many livestock, rice fields, and fields of people who died before they could be harvested. In addition to the long dry season, the damage at the water gate of Karanganyar, for more precisely in Kali Wulan, due to the War of Independence since late 1945 also exacerbated this condition.

The area that suffered the most as a result of the drought was Kawedanan Wedung whose citizens were 33,000 people. Many residents were working on drilling wells and stemming the Tempuran Angin-Angin, Kenceng, Gojoyo Rivers but the results were also not optimal. Meanwhile, some were trying to find drinking 
water in the village of Mijen, precisely in the old Kawedanan Wedung. However, it was difficult for people to reach the village due to long travel time and expensive cost. Finally, many of those were desperate and migrated or left their house to go to Semarang (Suara Merdeka, 15 August 1950:2).

On September 1952, the urbanization flows happened again from the east and west border of Semarang. Harvest failures due to flood and the long rainy season were the main cause (Suara Merdeka, 16 September 1952:4).

On January 1954, Mount Merapi disaster caused many residents around the slopes to evacuate. About 4,000 residents would be evacuated to safe places (Suara Merdeka, 21 January 1954:1). In addition to addressing the issue of evacuation, donations for victims of erupted Mount Merapi were also established by several governmental and private agencies. This condition also indicated the emergence of MMC gangs who was suspected began their action in Semarang (Suara Merdeka, 28 January 1954:2).

Therefore, the growth of banditry roots was affected by social. economic, political condition during the post-war independence. The running revolution economy was not able to meet the needs of the people of Semarang. In addition, the administration of government bureaucracy and security of the territory requiring a long time and less personnel, causing the emergence of bandits and facilitate the bandit to perform their action in Semarang.

\section{The Bandits Action}

In Semarang, criminal acts have various terms. Some crimes could be categorized as banditry acts because they had some bandit terminology, such as a robber, a person who steals and kills cruelly and unashamedly, and the enemy of all law enforcers. (Gove, 1976:170 in Suhartono, 1995:93) Bandits acting in Semarang had various names, such as garong, begal, burglar, and robber. The different name refers to the objective of bandit operation. Below are some of the dominant banditry cases in Semarang, among others:

\section{Street Robbery}

Pembegalan (street robbery) comes from a basic word "begal" meaning a bandit who plunder on the road (Tim Penyusun Pusat Pembinaan dan Pengembangan Bahasa, 1999:105). The street robbers run their action without knowing the time and are always accompanied by threats to the victims. Some of the acts of street robbery were reported by Suara Merdeka daily. The first street robbery happened on the head of the foreman of the Borsumij company in Kampung Duwet during the afternoon between 13:00 and 14:00, May 5, 1950. When the victim had just left the Abdulkadir shop and walked towards the rest area of Tan Oei, suddenly he was approached by two people who forced him to hand over his money. The victim was powerless to refuse and hand over the money of approximately of 600 (Suara Merdeka, 6 May 1950). 
One of examples of the above street robbery event was obtained from Suara Merdeka newspaper and from this newspaper, it was also known that the year with the greatest street robbery cases was in 1950 with 21 cases. This great number was related to the excesses of the revolution that created a city situation that was not yet completely secure and stable. While in the following years, the street robbery intensity declined considerably compared to what happened in 1950, not even ten cases in a year.

The second analysis was related to the use of firearms by the begal. In 1950, there were 18 cases then continued to decline in subsequent years, not even up to five cases in a year. This condition occurred because of the implementation of Emergency Law of the Republic of Indonesia Number 12 of 1951 on firearms that were applied strictly. For the perpetrator who was caught to have firearm shall have been threatened to have death penalty as the maximum penalty.

Third, street robbers targeted quiet road located in villages in the city of Semarang. This proved that the villages in Semarang were not safe because almost every year, street robbery case always happened, even in public roads, this crime also happened. In addition, the border area of the city was also quite prone to this street robbery. These conditions also illustrated that the polices in Semarang did not yet work well.

Fourth, there were various goods grabbed by the begal, ranging from merchandise, cars, luggage, jewelry, motor cycles, and so on. This showed that the street robbers were not picky in action. All the goods carried by the victim were grabbed. Such actions could not be separated from the city condition in 1950's when there was food scarcity.

Fifth, some of begal worn military attributes. This could be associated with Rera's policies that had been enacted at the central and regional levels, so that some frustrated former fighters were exposed to this policy and unemployed choose to be begal. Meanwhile, there were more street robbers appearing along with the unstable condition of the city. However, following the enactment of the Emergency Law of the Republic of Indonesia Number 12 of 1951 on firearms, the number of street robbery decreased. This condition was also inseparable from some security operations performed by police and soldiers in line with the implementation of the law in Semarang.

Sixth, not all street robbery target was woman. In carrying out their action, begal did not select their victims, they could be women or men. This also occured at the time of the street robbery for the seventh analysis. The street robbery also did not consider the time. It could happen any time.

Seventh, most of street robbery cases occurred in Semarang were not handled well by police. Some cases even ended without any complete clarification. Meanwhile, from the data obtained, it showed that some street robbers could escape when they were already trapped by police or even after performing the action, even they used vehicles such as cars and bicycles. Therefore, it could be said that at that time, the police performance was considered weak in ensuring the citizen security. 
Eighth, the street robbers almost never worked individually. They always worked in groups. Minimum, there had be two persons performing the action.

\section{Burglary}

Locally, burglar in Semarang are often called as "maling". They were the ones who took others' property in secret (Tim Penyusun Kamus Pusat Pembinaan dan Pengembangan Bahasa, 1999:622). Those considered as maling were often simplified as burglar. However, the notion in the Legal Dictionary defines burglar as the ones who are against the law by taking others' property at night (Sudarsono, 1992:262).

The first burglary case was published in Suara Merdeka daily, it took place at Gudang Kancil Mas Warehouse in Oosterwalstraat (around the Old Town area) on May 23, 1950 at five in the morning. The warehouse was visited by four burglars who entered the barn by breaking the tiles. The four burglars succeeded to take most of the textile materials which were estimated to be worth approximately f 20,000. A witness who knew the incident stated that he saw the burglar hide his loot not far from Gudang Kancil Mas, which was near to the railway carriage. After the investigation, the police managed to catch two of the four burglar and secured 15 blocks of stolen textile (Suara Merdeka, 24 May 1950:2). ${ }^{2}$

First, the burglary case above was one example of a case processed from the Suara Merdeka daily newspaper. Based on the comprehensive data analysis from Suara Merdeka daily, the year with the highest level of burglary cases occurred in 1950 with nine cases. This great number could be associated with the excesses of the revolution that created a city situation that was not yet completely secure and stable. In addition, economic conditions that have not yet recovered led to the rise of burglary cases. While in the following years the intensity of burglary cases declined considerably compared to what happened in 1950, not even ten cases in a year.

Second, most of the thieves preferred sharp weapons to firearms, although there were several burglary cases carrying firearms. This was because the thief did not directly come into contact with the victim as in the begal. Burglary cases were usually known the next day or after the victim made report to the police. However, the issue of firearms ownership was also special concern, because thieves who were considered not to require firearms turn out to have firearms easily in those days. Illegal firearms ownership was still occurred in 1950 before the Emergency Law of the Republic of Indonesia Number 12 of 1951 enacted.

Third, house was the most potential target for burglary because it was easier to break and enter into the house than warehouse or store that was definitely secured by a security officer. The houses were also dominantly located in the village. This also showed that the police have not maximized in securing the city, even into the villages.

Fourth, burglars almost never worked individually. They always attempted to do burglary in group, minimum two people.

${ }^{2}$ One block can be defined as a roll of cloth of which the weight is around 25 kilograms with various length depending on the cloth thickness 
Fifth, the items taken by burglar varied greatly, ranging from merchandise, cars, luggage, jewelry, motor cycles, and so on. This showed that burglars were not picky in action. All the goods carried by the victim were grabbed. Such actions could not be separated from the city condition in 1950's when there was food scarcity.

Sixth, none of perpetrators worn military attributes. This showed that most of burglar were purely civilians. The difficult economic conditions in those days caused a some of people attempt to do burglary.

Seventh, all of burglar target was not women. In doing burglary, they did not point out to women, yet they prefer to take immobile goods to the owner or ones at home.

Eighth, burglary tended to occur at night because many victims were less likely to be careless and security at night was not so maximized. Burglar could freely break down the contents of the house, warehouse, or store.

Ninth, most of burglary cases could be handled by police but with long term period. They still could escape when they were trapped by citizens or police during the action. This shows that the use of firearms was more dangerous than the use of sharp weapons. Burglar having sharp weapon was easy to traced and caught by the police.

\section{Robbery}

Robbery's root word is robber which is defined as a person who commits to take others' property by coercion and violence (Tim Penyusun Kamus Pusat Pembinaan dan Pengembangan Bahasa, 1999:815). Suhartono equates robber with "gedor" in the banditry tradition in the countryside. The word "gedor" is identical with violence that is equalized by the act of knocking on the door loudly. Semarang, which borders with rural areas in east, south and west, is still familiar with the criminal terms.

The first recorded robbery occurred at night on April 28, 1950. The robbers used army uniform and attacked a Chinese living in Jalan Pedamaran Number 39 A. The robber was three and two of them carried a revolver. They forced the host to hand over his valuable goods. Finally, the robbers managed to seize cash worth approximately f 400, a hand watch, and a key to the vault (Suara Merdeka, 29 April 1950:2).

First, the above example was one of the robbery cases that occurred in 1950. Based on data processed from Suara Merdeka daily newspaper, the year with the greatest number of robbery cases was in 1950 with 38 cases. This great number of cases could be associated with the excesses of the revolution creating a city situation that was not yet completely secure and stable. In addition, economic conditions that had not been recovered led to the rise of robbery cases. While in the following years the intensity of robbery cases declined considerably compared to what happened in 1950, not even ten cases in a year.

Second, the analysis was related to the use of firearms by the begal. In 1950, there were 29 cases then continued to decline in subsequent years, not even up to ten cases in a year. This condition occurred because of the implementation of Emergency Law 
of the Republic of Indonesia Number 12 of 1951 on firearms that were applied strictly. For the perpetrator who was caught to have firearm would be threatened to have death penalty as the maximum penalty

Third, house was the most potential target for burglary because it was easier to break and enter into the house than warehouse or store that definitely secured by a security officer. The houses were also dominantly located in the village. This also showed that the police had not been maximized in securing the city, even into the villages.

Fourth, the robbers almost never worked individually. They always attempted to do robbery in group, minimal two people.

Fifth, the items taken by robbers varied greatly, ranging from merchandise, cars, luggage, jewelry, motor cycles, and so on. This showed that the robbers are not picky in action. All the goods carried by the victim were grabbed. Such actions could not be separated from the city condition in 1950's when there was food scarcity.

Sixth, some of robbers wore military attributes. This could be associated with Rera's policies that had been enacted at the central and regional levels, so that some frustrated former fighters were exposed to this policy and unemployed choose to be robber. Meanwhile, there were more robbers appearing along with the unstable condition of the city. However, following the enactment of the Emergency Law of the Republic of Indonesia Number 12 of 1951 on firearms, the number of robbers decreased. This condition was also inseparable from some security operations performed by police and soldiers in line with the implementation of the law in Semarang.

Seventh, not all of robbers' target was not women. In doing robbery, robbers did not point out to women, yet they preferred to take immobile goods to the owner or ones at home.

Eighth, the robbery action could happen any time. However, robbery tended to occur at night because many victims were less likely to be careless and security at night was not so maximized. Robber could freely break down the contents of the house, warehouse, or store.

Ninth, most of robbery cases in Semarang could not be handled by police maximally. Some cases even ended without any complete clarification. Meanwhile, from the data obtained, it showed that some of the robbers could escape when they were already trapped by police or even after performing the action, even they used vehicles such as cars and bicycles. Therefore, it could be said that at that time, the police performance was considered weak in in ensuring the citizen security.

First, from the various descriptions above, it could be discussed several things. First, there were three factors that caused to the emergence of the banditry in Semarang, the Rera policy was enacted since June 1950 and the scarcity of food, and government that had not been well ordered including the not maximum police performance.

Second, the bandits in the above narratives were more dominated by pure bandits. Pure bandits were bandits from civil society who performed their actions to 
meet their life needs. They were very opportunistic. The bandits showed no principled attitude and they only looked for profit in the midst of unstable city conditions. In addition, in carrying out the action they worked in groups and attacked the victim any time.

Third, not all the news contained in Suara Merdeka daily reported banditry in Semarang, while there was no source from the Semarang police. Therefore, the news about the bandit's recklessness with illegal firearms raised the concerns of Semarang residents. The circulation of illegal firearms had only been regulated after the emergence of emergency law of the Republic of Indonesia Number 12 of 1951 on firearms with the threat of death penalty for the owner.

\section{Countermeasures}

When the number of law enforcer that was not comparable with the banditry actions had disturbed citizens of Semarang, then the existence of private security organizations had a place in the middle of the citizens. The members of this organization mostly came from members of the army or fighters in the era of the Independence Revolution.

The aim at involving former fighters was to protect them from being involved as bandits. Several former fighters initiated the formation of several private security organizations. All of these private security organizations were under the coordination of the Semarang Military Office. However, if the working area covered Central Java, the security organization had to be under the coordination of the Central Java Territory Military IV. In general, this security organization was divided into two types, namely private security organizations established independently by the former fighters and security organizations formed by the government named People's Defense Force.

As already feared before, that Semarang was prone to illegal firearms trade. Even the circulation of weapons also involved law enforcer. One of the cases decided by the Semarang Military Court on November 7, 1955 was the misuse of firearms by a soldier with the initials $\mathrm{Dj}$. The perpetrator holding the pistol and its bullet were charged with negligence in assuming responsibility for guarding and misusing firearms for the banditry action. The history of firearms ownership was disclosed by the perpetrator recognition that he obtained the gun when he carried out his duty in Ambon as a member of the Unity of DSS TT IV, Diponegoro Division. The gun was lent to a friend who was actually used it to do robbery in Weleri. For the Perpetrator's actions, the court sentenced him to two years in prison. Punishment in accordance with the prosecutor's demands (Suara Merdeka, 8 November 1955:2).

A similar case occurred again to former employees, with initial $\mathrm{J}$, at the Semarang Police Office who chose to resign since October 1955. He domiciled at Jatingaleh. The perpetrator was arrested by police at a bus stop near to Apotik Bangkong because the Police found a Colt firearm. The illegal firearms according to the perpetrators were obtained by chance in 1949 in the Jatingaleh military gangway ditch. On the basis of the finding, the perpetrator did not report his findings to the 
police and chose to keep them. Another reason that the perpetrator delivered because he worked in the police station, so the firearms ownership was considered no harm. After he resigned from his work, the firearm was about to be sold to a fellow police officer for Rp 2,000 (Suara Merdeka, 4 December 1956:2).

Another effort to anticipate illegal firearms circulation was by organizing a renewal of firearms registration in Semarang for the period of 1957. For firearms holders, either as owners or individual borrowers from general civil citizen were required to re-register their firearms to the Semarang Police Office at Jalan Bojong number $123 / 125$ room number 11 . This administrative office was open every working hour. When the owners processed the ownership permit, they were required to bring a license (fit) model of firearms of XVII A or B type, duty stamp paper (Dutch: plakzegel), and of course the firearms. Such registration took place from 1 January to 31 March 1957 (Suara Merdeka, 27 December 1956:2).

Not all appeals and enforcements of firearms registration were obeyed by Semarang residents. However, on March 5, 1957 the Military Police Corps performed search in Drogisterij (Netherlands: drug store) "Quick" located at Jalan Mataram, estimated to be a place for firearms, they found a number of firearms. In the search, it was found several firearms such as three dobel loops firearms, one chas, one mauser weapon, and a small gun (pistol dames ). Of all firearms found, firearms having license or registered legally for hunting purposes were only pistols dame. In addition, it also was found 38 rounds of 7.7 Jungle Rifle caliber bullets, two of them did not have license. The owner of Drogisterij "Quick" initials LThL was immediately arrested by Military Police Corps and his case was immediately submitted to the public prosecutors. On the other hand, the one with initial LWH who worked at the soap company Lies Industrie was also arrested for storing the illegal Bulldog gun in his car (Suara Merdeka, 6 March 1957:2).

Furthermore, Semarang government through law enforcers, both police and soldiers also tried to prevent illegal firearms by checking every member of the security forces entering Semarang. Some soldiers were apparently carrying firearms without permission from their units. This case occurred to one of the soldiers from a unit in Jakarta who had just descended from the Zwarte Hond ship at Semarang Harbor on 27 March 1957 (Suara Merdeka, 6 March 1957:2). The firearms carried by the soldiers were eventually confiscated by law enforcers in Semarang.

Army Commander of Territory IV of Central Java reminded and reiterated the law and regulation on the firearms ownership on June 13, 1957. The regulations contained in the Emergency Law No. 12 of 1951 on Provisional Rules of Interim Penalties contained in the State Gazette of 1951 Number 78. The regulation also stipulated the apparatus of either the police, military or certain civilian in Central Java who might own, try, keep, use, issue, enter, transport, and surrender firearms for the sake of personal safety. These officials included all members of the armed forces including civil officer of titular military, member of police officers, private persons assisting police and state troops' duties, and civil servants from subdistrict head to the upper position. In addition, there were still some official servants, such as 
imprisonment, forestry, pawnshops, traffic, duties and excise, PTT, state plantations, volcanoes, state mining, state banks, state treasuries, and state courts, both prosecutors and Clerk who had the right to have a firearm. In the meantime, there were still people who had certain jobs given permission to own firearms, such as amateur and professional hunters, licensed hunting gunmen, and repairmen of hunting weapons who must also be licensed. For the Sultanate Palace of Yogyakarta, Surakarta, Mangkunegaran, and Paku Alaman also got the privilege of owning firearms (Suara Merdeka, 14 June 1957:2). The limitation made by the Central Java Military Ruler aimed to stop the circulation of illegal firearms that were still in circulation and still easy to obtain.

Police Residency Semarang and Semarang at the beginning of each year always held a regular registration of firearms. For firearms holders, either as individual owners or borrowers from general civil population were obliged to re-register their firearms to the Residency Police Station / Semarang on Jalan Bojong 123/125 number 11. This administrative office was open every working day from Eight to 12 noon, while every Friday is only till eleven o'clock in the morning. When processing ownership permit, the owners were required to bring a license (pas) model of firearms of type XVII A or B, duty stamp paper (Dutch: plakzegel), and of course the fire weapon. The registration took place from 1 January to 31 March 1958 (Suara Merdeka, 14 December 19572).

Police conducted various arrest modes to detain the aggression of the bandits. There were three strategies in overcoming the bandits in Semarang. First, the result of cooperation among local polices around Semarang.

Mobbrig Police Action to detain the movement of MMC members suspected to be screwed Semarang continued to be performed. In the early hours of January 2, 1954 Mobrrig Police and Boja Limbangan Police carried out patrol and reconnaissance on unexpected MMC members in the area. Police finally managed arrests while they were watching a ketoprak show in the hamlet of Watulawang, Boja District, Kendal. The arrest began, when police began to dissolve the show by firing a gun into the air and warning the MMC sympathizers to surrender.

There were no casualties in the incident. The MMC sympathizers had fought back with fire, but because they were trapped by police forces, finally they surrendered. There were 10 of 14 members of the MMC arrested and one of them was woman. Four others were released after a deep investigation; it was found that they were not involved in the MMC movement. The evidence seized from the arrest was a houderbak (Dutch: silinder to keep the bullet) with 25 bullets and important papers. Five arrested people proved to be members of MMC. While the rest allegedly acted as an introductory messenger of information, which could be known from the contents of a letter from MMC officials who hid in Mijen. Ten MMC sympathizers were eventually arrested by the police (Suara Merdeka, 6 January 1954:2).

Second, reconnaissance. Semarang Police continued to conduct surveillance against gedor plotters who attacked the workshop Excelsior Semarang. The workshop suffered heavy losses because the merchandise was seized by the gedor. 
Total loss was approximately 19,000. Three of gedor were arrested by police on May 25, 1950 (Suara Merdeka, 26 May 1950:2).

Third, the development of previous cases. Two police officers from the Central Java Provincial Police Office, Ong Tiong Giem and Kardjono managed to uncover the crime of gangster bandit that had been troubling residents in Semarang and in other cities in Central Java. Their actions such as street robbery, robbery, burglary, and other criminal banditry by using firearms had been paralyzed. This was the biggest arrest.

Sutrisno who became bengkol as well as the one who prepared and planned the banditry was successfully arrested in Semarang after a series of surveillance conducted by the police. Together with his bandit friends, he was suspected to launch his action in a house on Jalan dr. Cipto. The house belonged to a food entrepreneur who also supplied logistics needs in prison houses in Semarang. In the arrest on January 3, 1958, there were nine bandits successfully arrested besides Sutrisno, namely Idi, Bertus Ong, Tjioe Siong Liem, Johny Sumarno, Oei Sing Hien, Lie Tjing Hien, Mulyono and Modhalil. In the arrest operation, FN revolver was seized from Sutrisno's hand (Suara Merdeka, 4 January 1958:2).

\section{Conclusion}

Based on the above descriptions and referring to the problems formulated in this article, it can be drawn up the following conclusions. First, the roots of banditry in Semarang emerged due to economic difficulties that occurred in the early 1950s, so to meet their life needs, the banditry targeted all the victims without any exceptions. The economic difficulties were shown from the distribution of food, clothing, shelter that did not work properly. It was coupled with various social problems occurring in Semarang, such as the emergence of unemployment, homeless, refugees, and criminality.

Second, the origin of bandits in Semarang was dominated more from the villages in Semarang. This condition could be understood because the citizens were not used to live in subsistence way and they only rely on the trade and services sector, so they have no other choice when experiencing economic pressure. They were forced to become bandits, such as thief, street robber, burglar, and robber. In addition, they moved more dominant in groups that were not well organized.

Third, in order to deal with and overcome the actions of the bandits who troubled Semarang, the local government, police, military, and citizens tended to be reactionary. They only gave responds after banditry cases had occurred, so the repressive nature was preferred in overcoming banditry in Semarang. This shortterm countermeasures option was as a consequence of the emergence of a new government during post-war of Independence requiring immediate the restoration of conditions. Consequently, the success of short-term banditry handling was seen only from various security operations, firearms control, and bandits arrest. 


\section{References}

Abdullah, Taufik. Bab I Pengantar ke Sejarah sebagai Disiplin Ilmu, paper presented at Seminar Nasional Pekan Cinta Sejarah, Pontianak, 18-22 November 2013.

Budi, Langgeng Sulistyo, 1997/1998. Permasalahan Sosial Perkotaan pada Periode Revolusi: Kriminalitas di Yogyakarta 1947-1948, Lembaran Sejarah, Vol. 1, No. 2.

Djamhari, Saleh (2012). A. Kegelisahan Pascaperang, in Abdullah, Taufik and A. B. Lapian (ed.) Indonesia dalam Arus Sejarah: Pascarevolusi. Jakarta: Ichtiar Baru van Hoeve and Ministry of Education and Culture of Indonesia.

Fauzi, M. (2005). Lain di front, lain pula di kota: Jagoan dan Bajingan di Jakarta Tahun 1950-an, in Colombijn, F. (ed.) Kota Lama Kota Baru: Sejarah Kota-Kota di Indonesia. Yogyakarta: Ombak.

Gove, Philip Babcock (1976). Websters Third New International Dictionary. Massachusetts: G.\& C. Merriam Co., in Suhartono (1995). Bandit-Bandit

Pedesaan: Studi Historis 1850-1942 di Jawa. Yogyakarta: Aditya Media.

Ibrahim, Julianto (2004). Bandit dan Pejuang di Simpang Bengawan: Kriminalitas dan Kekerasan Masa Revolusi di Surakarta. Wonogiri: Bina Citra Pustaka.

Kuntowijoyo (2005). Pengantar Ilmu Sejarah. Yogyakarta: PT Bentang Pustaka.

Lucas, Anton E. (1989). Peristiwa Tiga Daerah: Revolusi dalam Revolusi, translated by Pustaka Utama Grafiti. Jakarta: Pustaka Utama Grafiti.

Notosusanto, Nugroho (1964). Hakekat Sejarah dan Metode Sejarah. Jakarta: Mega Book Store dan Pusat Sejarah Angkatan Bersenjata.

Poeponegoro, Marwati Djoened and Nugroho Notosusanto (2010). Sejarah Nasional Indonesia VI: Zaman Jepang dan Zaman Republik Indonesia ( \pm 1942-1998). Jakarta: Balai Pustaka.

Purwanto, B. (2005). Kekerasan dan Kriminalitas di Kota pada Saat Transisi: Kotagede, Yogyakarta pada Akhir Masa Kolonial dan Awal Kemerdekaan, in Colombijn, F. (ed.) Kota Lama Kota Baru: Sejarah Kota-Kota di Indonesia. Yogyakarta: Ombak.

Ricklefs, M. C. (1992). Sejarah Indonesia Modern, translated by Dharmono Hardjowidjono. Yogyakarta: Gadjah Mada University Press.

Sudarsono (1999). Kamus Hukum. Jakarta: Rineka Cipta.

Tim Penyusun Kamus Pusat Pembinaan dan Pengembangan Bahasa (1999). Kamus

Besar Bahasa Indonesia Edisi Kedua. Jakarta: Balai Pustaka.

“2500 Anak-Anak Tentara Pelajar akan Kembali ke Masyarakat”, Suara Merdeka, 21

April 1950.

“3 Orang Kaki Tangan Penggedor Ketangkap”, Suara Merdeka, 26 May 1950.

"Dibegal Di Jalan Umum Duwet", Suara Merdeka, 6 May 1950.

"Dompet Merapi”, Suara Merdeka, 21 January 1954.

“Kalau Gerombolan Nonton Kethoprak”, Suara Merdeka, 6 January 1954.

“Kesukaran Tentang Air Minum”, Suara Merdeka, 15 August 1950.

"Keterangan Wiwoho: Tentang Pengembalian Jawa Tengah", Suara Merdeka, 11 February 1950.

“Komplotan Bandit-Bandit Ulung Dibekuk Polisi”, Suara Merdeka, 4 January 1958. 
“Lagi ‘Kancil Mas' Dibongkar Pencuri”, Suara Merdeka, 24 May 1950.

"Lebih Kurang 10.000 Orang Tentara akan Kembali ke Masyarakat", Suara Merdeka, 26 May 1950.

“Lebih Kurang 70.000 Orang akan Kembali ke Masyarakat", Suara Merdeka, 5 June 1950.

“Menjual Senjata Api”, Suara Merdeka, 4 December 1956.

“Menyimpan Senjata Tanpa Izin”, Suara Merdeka, 8 November 1955.

"Merapi Tetap Berbahaya", Suara Merdeka, 21 January 1954.

"Mereka yang Diizinkan Membawa Senjata Api", Suara Merdeka, 14 June 1957.

"Pendaftaran Senjata Api", Suara Merdeka, 14 December 1957.

"Perampok di Pedamaran 39 A", Suara Merdeka, 29 April 1950.

"Ramalan Hujan", Suara Merdeka, 16 September 1952.

"Rampok Menembak Mati Pegawai DPU di Siang Hari", Suara Merdeka, 28 January 1954.

"Senjata-Senjata Gelap Ketemu di Semarang", Suara Merdeka, 6 March 1957.

"Turun dari Kapal Senjata Disita", Suara Merdeka, 28 March 1957. 